\title{
MENCARI FORMAT BARU PENDIDIKAN BERBASIS MULTIKULTURAL DI INDONESIA
}

\author{
Tanto Sukardi \\ Universitas Muhammadiyah Purwokerto \\ E-mail: tanto_sukardi@yahoo.com \\ Subandowo \\ Universitas PGRI Adi Buana Surabaya \\ Email: subandowo@yahoo.co.id
}

\begin{abstract}
This article aims to find a new format of education based multicultural reality in Indonesia. For that purpose, the authors conducted a literature study, especially those related to the concepts of multicultural education for the development of education in Indonesia. As it is known that the current Indonesian society is still in the process of forming a national culture. This is not an easy task, because of the heterogeneous ethnic cultures that have each own character. When the formation of a national culture has not been successful, the people of Indonesia also have to deal with the increasingly intense global culture. Pressures of today's global culture is sometimes met with reactionary and primordial attitude. As evidence, the emergence of a kind of spiritual religious movement radicalism and fundamentalism form of Sufism on youth. Meanwhile, the traditional sentiment which is basically a consequence of the structural changes and cultural changes inkosisten, resulting in the emergence of symptoms of chaos in the system of local cultural values that exist. These conditions are necessary to find a way out so that the process of interaction between local cultures remain in harmony with the national culture. Format suitable for the purpose as it is through multicultural education.

Keywords: local culture, national culture, multicultural education
\end{abstract}

\begin{abstract}
Abstrak
Artikel ini bertujuan untuk mencari format baru pendidikan berbasis multikultural di Indonesia. Untuk tujuan tersebut penulis melakukan studi kepustakaan, terutama yang berhubungan dengan konsep-konsep pendidikan multikultural untuk pengembangan pendidikan di Indonesia. Seperti diketahui bahwa saat ini masyarakat Indonesia masih dalam proses untuk membentuk budaya nasional. Ini bukan tugas yang mudah, karena budaya etnis heterogen yang masingmasing memiliki karakter mereka sendiri. Ketika proses pembentukan budaya nasional belum berhasil, masyarakat Indonesia juga harus berhadapan dengan budaya global yang semakin gencar. Tekanan budaya global saat ini kadang-kadang ditanggapi dengan sikap yang reaksioner dan primordial. Sebagai bukti, munculnya spiritual gerakan keagamaan semacam radikalisme dan fundamentalisme bentuk sufisme pada pemuda. Sementara, dari sentimen tradisional yang pada dasarnya merupakan konsekuensi dari perubahan struktural dan perubahan budaya yang inkosisten, mengakibatkan munculnya gejala kekacauan dalam sistem nilai-nilai budaya lokal yang ada. Kondisi seperti ini perlu dicari jalan keluarnya agar proses interaksi antara budaya lokal tetap harmoni dengan budaya nasional. Format yang sesuai untuk maksud seperti ini adalah melalui pendidikan multikultural.
\end{abstract}

Kata kunci: budaya lokal, budaya nasional, pendidikan multikultural 


\section{A. Pendahuluan}

Sejak berdirinya pada tanggal 17 Agustus 1945 Indonesia merupakan suatu negara kebangsaan (nation state) yang dibangun atas dasar masyarakat multi budaya dan multi etnis ke dalam suatu bentuk kesatuan nasional. Budaya etnis yang sangat beragam juga berkembang menurut dinamika sejarah yang dialami masingmasing pendukungnya yang ada di berbagai daerah. Kondisi masyarakat dan budaya yang pluralistik inilah yang diintegrasikan dalam bingkai nasionalisme yang mengikat solidaritas lokal menjadi solidaritas nasional. Proses transformasi semacam itu berlangsung dalam masyarakat yang mengarah pada upaya mewujudkan budaya nasional baru yang disebut dengan budaya Indonesia modern.

Dalam kenyataannya proses transformasi dari masyarakat agraris tradisional menuju masyarakat modern diwarnai dengan kemajemukan unsur budaya yang cair dan terbuka. Kondisi demikian menyebabkan proses dialog antar unsur kebudayaan yang mengarah pada format baru itu, menjadi sangat rumit dan tertatih-tatih. Berkaitan dengan itu, Kayam menyatakan, bahwa dalam proses transformasi itu harus selalu dihindari suatu strategi kebudayaan yang memaksakan homogenitas yang monolitik dari kenyataan kemajemukan. Dari sinilah kemudian muncul ide dan gagasan perlunya disusun format baru pendidikan yang berbasis pada kebhinekaan yang sesuai dengan situasi dan kondisi masyarakat Indonesia saat ini. ${ }^{1}$

Memasuki dekade terakhir ini Indonesia masih dihadapkan pada persoalan-persoalan pokok yang berkaitan dengan pembentukan budaya nasional. Hal itu ternyata bukan persoalan mudah, mengingat begitu beragamnya budaya etnis yang masing-masing mempunyai ciri dan dinamikanya sendiri. Jika dicermati, proses pembentukan budaya nasional dalam masyarakat yang beragam etnis itu ternyata tidak selalu berjalan mulus, karena budaya nasional yang sedang dalam proses pembentukan itu harus pula berhadapan dengan arus budaya global. Hal ini menyebabkan terjadinya pergeseranpergeseran budaya lokal maupun nasional dalam rangka mencari kemapanan diri. Proses mencari bentuk dan jati diri bangsa Indonesia melalui identitas budaya lokal, nasional, dan global itu tidak jarang justru mendatangkan konflik dan ketegangan antaretnis di berbagai daerah. Hal ini perlu perhatian yang cermat dan kebijakan yang tepat, agar negara nasional yang dibangun tetap kokoh. Salah satu kebijakan yang strategis adalah dikembangkannya format baru pendidikan yang berbasis pada prinsip kebhinekaan sebagai suatu kebijakan yang sangat mendesak.

Untuk dapat melihat pendidikan yang berbasis pada kebhinekaan yang sesuai, maka sangat perlu berkaca pada pengalaman sejarah masa lampau. Pelajaran pahit dari pengalaman sejarah telah membawa kelompok-kelompok etnis berproses menuju ke arah pembentukan negara bangsa, bukan negara wangsa. Dua istilah itu disepakati sebagai pedoman untuk membentuk nation state dan bukan national state. Istilah yang satu bertitik tolak pada kesatuan wilayah atau teritory dengan keragaman suku, sementara istilah yang kedua metitik beratkan pada suatu suku (ethnisity) dengan keragaman wilayah. Dengan pemahaman nasionalisme semacam itu, rakyat pribumi di berbagai daerah dengan beragam budaya dan etnis melancarkan penolakan terhadap segala bentuk dominasi dan penjajahan. Keberhasilan perjuangan dengan paham nasionalisme semacam itu kemudian menjadi prasyarat bagi kehidupan Indonesia merdeka yang dirangkum dalam semboyan Bhinneka Tunggal Ika. ${ }^{2}$

Melihat kenyataan dewasa ini setelah lebih dari enam dekade kemerdekaan Republik Indonesia dilalui, dirasa perlu untuk melakukan berbagai upaya penyegaran kepada generasi muda melalui pendidikan yang berbasis pada kebhinekaan yang berorientasi kepada upaya mempertahankan idealisme Binneka Tunggal Ika yang tampak semakin jauh dari kehidupan masyarakat.

Bidang pendidikan merupakan suatu faktor yang sangat fundamental dalam upaya meningkatkan kualitas kehidupan, di samping juga merupakan faktor penentu bagi perkembangan sosial dan ekonomi ke arah kondisi yang lebih baik. Pendidikan juga

2 Parakitri, Negara Bangsa atau Negara Wangsa, Seminar tentang Nasionalisme di Salatiga, 1993, h. 7. 
dipandang sebagai sarana paling strategis untuk mengangkat harkat dan martabat suatu bangsa. Mengingat begitu pentingnya peran pendidikan bagi kehidupan masyarakat, maka pemerintah dewasa ini sangat memperhatikan segala aspek pendidikan yang ada untuk dikembangkan. Dengan harapan, agar pendidikan di Indonesia bangkit dan menjadi garda terdepan dalam pembangunan bangsa. Bentuk perhatian ini secara khusus tercermin dalam kebijakan pemerintah, antara lain yang berupa pemenuhan sarana perundang-undangan, peningkatan anggaran pendidikan, sampai pada upaya penyempurnaan berbagai regulasi yang berlaku untuk memajukan pendidikan nasional.

Kerja keras semacam itu tentu tidak lepas dari upaya melaksanakan amanat konstitusi yang diidamkan oleh para founding father negara ini. Pasal 31 ayat (2) Undang-Undang Dasar1945 mengisyaratkan, bahwa "Setiap warga negara wajib mengikutipendidikan dasardanpemerintah wajib membiayainya". Sementara itu pada Pasal 31 ayat (3) menyatakan, bahwa "Pemerintah mengusahakan dan menyelenggarakan satu sistem pendidikan nasional, yang meningkatkan keimanan dan ketakwaan serta akhlak mulia dalam rangka mencerdaskan kehidupan bangsa, yang diatur dengan undang-undang."

Dengan digulirkannya otonomi daerah yang secara resmi dilaksanakan sejak 1 Januari 2001, maka pengembangan pendidikan juga menjadi tanggung jawab pemerintah daerah masing-masing. Hal ini sejalan dengan tuntutan reformasi yang secara bertahap mengarah kepada penyelenggaraan otonomi daerah yang semakin luas. Dalam bidang pendidikan, tuntutan reformasi lebih mengarah kepada proses desentralisasi pengelolaan pendidikan. ${ }^{3}$

Kebijakan yang baik tidak serta merta berbuah manis bagi rakyat di berbagai daerah. Salah satu dampak negatif dari kebijakan otonomi daerah adalah berkembangnya egosentrisme warga daerah, yang berupa tidak mengakui eksistensi kelompok masyarakat yang berasal dari daerah lain. Sebagai contoh kasus di Aceh telah terjadi pengusiran terhadap warga yang berasal dari daerah lain. Istilah putra daerah juga telah dimaknai dengan pengkotakkan

3 D. Supriadi, Reformasi Pendidikan Dalam Konteks Otonom Daerah, Yogyakarta, Adicita, 2000, h. 142. ekstrim. Bahkan tidak jarang merebaknya peristiwa konflik antar komunitas di Poso, Ambon, Kalimantan Barat, Kalimantan Tengah, Papua dan beberapa daerah lain. Bahkan sampai detik ini kita masih belum dapat melepaskan diri dari maraknya tawuran kelompok sosial, pelajar dan mahasiswa yang tidak jarang merenggut korban jiwa. Semua itu terjadi karena faktor yang sangat kompleks, terutama disebabkan kurangnya pemahaman terhadap keberagaman baik itu kelompok sosial, etnis, budaya, agama, serta pengaruh budaya global yang cenderung agresif dan penuh persaingan. ${ }^{4}$

\section{B. Ide Dasar Pendidikan Berbasis Multikultural}

Secara teoretis proses integrasi etnis maupun rasial ke dalam bingkai nasional yang padu memerlukan waktu yang sangat panjang. Untuk dapat memahami proses pembentukan suatu bangsa yang berbasis pada multi rasial kita perlu belajar dari pengalaman bangsa Amerika Serikat. Sebagai suatu bangsa yang besar yang kuat, Amerika Serikat ibarat mosaik yang terdiri dari kepingan-kepingan yang sangat beragam yang pada awalnya saling lepas, tetapi melalui suatu proses tertentu mampu membentuk suatu perpaduan yang solid, serasi, indah dan sangat mengagumkan. ${ }^{5}$

Bangsa Amerika Serikat sebenarnya berasal dari latar belakang rasial, budaya dan asal usul yang sangat beragam. Setelah melalui tahapan tertentu mereka saling berasimilasi sehingga dapat berkembang kepada tahapan berikutnya. Proses seperti itu terjadi berulangulang, sehingga akhirnya berhasil membentuk nasionalisme dalam sebuah negara bangsa (nation state). Sudah tentu hal ini membutuhkan waktu dan kondisi-kondisi tertentu. Pada tahap awal cita-cita masyarakat multirasial dan multikultural dibentuk melalui proses asimilasi kelompok minoritas ke dalam kelompok dominan. Kemudian pada tahap berikutnya berbagai kelompok tersebut mengasimilasikan dirinya sebagai masyarakat baru, sehingga terbentuklah suatu masyarakat bangsa sebagai

\footnotetext{
4 M. Natsir, Mencari Corak Perdamaian Dengan Sistem Multikultur; http://ace-informasibudaya.blogspot.com/2010/01/perdamaian-sistem-kultur. html, 2010, h, 1

5 Thomas Sowell, Mosaik Amerika: Sejarah Etnis Sebuah Bangsa, Jakarta: Pustaka Sinar Harapan, 1989, h. 5.
} 
hasil dari asimilasi tersebut. Proses seperti itu diabadikan dalam sebuah teori terkenal, yaitu teori melting pot. ${ }^{6}$

Teori melting pot pada awalnya diwacanakan oleh J.Hektor seorang imigran dari Normandia. Dalam teorinya dia menekankan penyatuan budaya dan melelehkan budaya asalnya, sehingga seluruh imigran Amerika hanya memiliki satu budaya baru, yakni budaya Amerika. Walaupun sekarang diakui, bahwa monokultur mereka itu lebih diwarnai oleh kultur White Anglo Saxon Protestant (WASP) sebagai kultur imigran kulit putih yang berasal dari Inggris yang Protestan. ${ }^{7}$

Teori ini sangat terkenal di Amerika Serikat sebagai cerminan dari proses terbentuknya bangsa itu yang tidak saja multietnis tetapi juga multi rasial dan multi budaya menjadi satu bangsa yang kuat. Jika dicermati kelompok etnis/ras satu persatu datang ke Amerika Serikat untuk mendapat kehidupan yang lebih baik dalam bidang politik, ekonomi, maupun agama. Perjuangan dilakukan oleh beberapa etnis sejak mereka meninggalkan tanah leluhur, sampai saat sekarang ini ketika pluralisme etnis/ ras dalam tubuh bangsa Amerika Serikat telah menjadi kenyataan dan diterima oleh berbagai pihak. Setiap kelompok etnis memperlihatkan kegigihannya dalam menghadapi berbagai kesukaran. Setiap kelompok mampu mengatasi bermacam-macam kesukaran dan hal ini merupakan indikasi kuat bagi mereka untuk dapat tumbuh menjadi kelompok masyarakat yang tegar, percaya diri akan kemampuan dirinya, dan tinggi pula harga dirinya. ${ }^{8}$

Dalam proses menuju integrasi antara etnis/ ras dalam masyarakat Amerika Serikat secara berangsur-angsur terbentuk filsafat hidup yang berjalan secara integrasional dan komulatif. Proses terbinanya suatu bangsa sampai sekarang merupakan proses yang panjang, merupakan proses yang penuh prasangka-prasangka etnis/ ras dan kultural, tetapi dengan kearifan kolektif semua hambatan itu dapat diatasi. Bersamaan dengan itu terbentuk pula kemauan yang kuat untuk membentuk identitas kultural baru, yaitu

\footnotetext{
6 Bill Watson, Multiculturalism: Its Strenth and Weaknesses, dalam JPIPS, No.23, Tahun XIII, Desember 2004, h. 15.

Dede Rosyada, Pendidikan Multikultural Melalui Pendidikan Agama Sebuah Gagasan Konsepsional: http://www.google.co.id/ search?hl=id\&client $=$ firefox-a\&rls=org.mozilla:en-US:official\&q=MULTI+KUL TUR\&start $=30 \& s a=$ N, 2010, h. 1 . 8 Op.Cit., h. 8.
}

identitas kultural Amerika Serikat yang bersifat multietnis/multirasial. Dalam masyarakat Amerika Serikat, kelompok-kelompok etnis/ras, seperti Inggris, Jerman, Irlandia, Yahudi, Italia, Negro, Jepang, Cina dan Indian, masing-masing memberi sumbangan terhadap pertumbuhan budaya bangsa Amerika Serikat.?

Kemudian ketika komposisi etnik dan ras di Amerika kian beragam dam majemuk, maka teori melting pot tidak sesuai lagi, sehingga muncul teori baru yang disebut teori salad bowl (gadogado) sebagai teori alternatif yang dipopulerkan oleh Horace Kallen. Teori salad bowl tidak melehkan budaya asal, tetapi sebaliknya kulturkultur lain di luar WASP diakomodasi dengan baik dan masing-masing memberikan kontribusi untuk membangun budaya Amerika sebagai sebuah budaya nasional. Pada akhirnya interaksi antar berbagai etnik/ras tetap masingmasing memerlukan ruang gerak yang leluasa. Hal ini kemudian melahirkan teori Cultural Pluralism, yang membagi ruang pergerakan budaya menjadi dua. Dua ruang gerak itu adalah: 1) Ruang gerak publik untuk seluruh etnik/ras mengartikulasikan budaya politik dan mengekspresikan partisipasi sosial politik mereka. Dalam konteks ini mereka homogen dalam sebuah tatanan budaya Amerika. 2) Ruang gerak privat, yang di dalamnya mereka mengekspresikan budaya etnis/ras mereka secara leluasa. ${ }^{10}$

Teori-teori tersebut dikembangkan dalam rangka memperkuat bangsa Amerika, membangun persatuan dan kesatuan dan mengembangkan kebangsaan serta warga negara Amerika Serikat. Namun demikian pada dekade 1960 an masih ada sebagian masyarakat Amerika yang merasa hak-hak sipilnya belum dapat dijamin sepenuhnya. Hal itu memunculkan pemikiran baru agar semua kelompok masyarakat dapat hidup nyaman, aman, dan tenteram dan terjamin hak-haknya. Kelompok Black America, imigran dari Amerika Latin, atau kelompok minoritas lainnya memerlukan cara baru yang sesuai dengan tuntutan baru, karena cara-cara yang sudah ada tidak tepat lagi. Untuk kepentingan itu maka mereka mengembangkan teori multiculturalism, yang menekankan pada

\footnotetext{
$9 \quad$ Ibid, h. 8.

10 Op.Cit., h. 1-2.
} 
penghargaan dan penghormatan terhadap hak-hak minoritas, baik dilihat dari segi etnik, agama, ras, atau warna kulit. Pada hakikatnya multikulturalisme adalah sebuah konsep akhir untuk membangun kekuatan sebuah bangsa yang terdiri dari berbagai latar belakang etnis, agama, ras, budaya, dan bahasa dengan menghormati dan menghargai hak-hak sipil mereka termasuk menghormati hak sipil kelompok minoritas. Sikap apresiatif tersebut dapat meningkatkan partisipasi mereka dalam membangun suatu bangsa. Pada dasarnya mereka menjadi besar karena kebesaran bangsanya dan mereka memiliki kebanggaan terhadap kebesaran bangsanya itu. ${ }^{11}$

Di Indonesia sendiri sebagaimana telah dinyatakan di atas telah menyadari tentang adanya kemajemukan ragam etnik dan budaya masyarakatnya. Indonesia sebagai suatu negara didukung oleh keberagaman etnis, budaya dan agama yang terbentuk oleh adanya persamaan sejarah, senasib-sepenanggungan, dan memiliki tujuan yang sama, yakni samasama ingin mencapai masyarakat adil, makmur, dan sejahtera. Akan tetapi, gagasan besar itu kemudian tenggelam dalam sejarah dan politik monokultur, baik yang dipraktekkan oleh Orde Lama maupun Orde Baru. Sistem Demokrasi Terpimpin yang diusung rezim Sukarno telah mematikan kreatifitas-kreatiftas lokal atau daerah yang berbasis etnik dan budaya tertentu. Kondisi pada periode Orde Baru di bawah kepemimpinan Suharto lebih parah lagi. Manajemen sentralistik yang dikembangkan rezim Suharto menjadikan filsafat Bhineka Tunggal Ika hanya tinggal slogan belaka. Upaya untuk mencapai kehidupan Bhineka Tunggal Ika tidak pernah terwujud dalam kenyataan empirik hubungan sosial maupun pranata sosial lainnya. ${ }^{12}$

Ketika simpul-simpul yang mengikat demokrasi terbuka pasca gerakan Reformasi, maka gagasan-gagasan yang terkait dengan kebhinekaan menjadi mengemuka dan langsung memasuki wilayah pendidikan dalam bentuk praktik. Seharusnya sebelum masuk pada tahapan realisasi, teori multikulturalisme di Indonesia dirumuskan terlebih dahulu oleh para

\footnotetext{
11 Ibid, h. 2.

12 Ibid, h. 2 .
}

ahli bidang sosial dan politik. Melalui teori yang dirumuskan itu akan memperoleh gambaran tipe ideal, jelas ruang lingkup dan batasbatasnya, serta bagaimana model pendidikan multikulturalisme yang seharusnya dilaksanakan. Atau setidaknya kita tidak akan dikacaukan oleh teori melting pot, salad bowldan lainnya yang pernah dilaksanakan di Amerika Serikat. Sebenarnya Indonesia memiliki perhatian yang sangat besar terhadap pendidikan yang tepat untuk mengikat kebhinekaan atau multi etnik, justru melalui pendidikan multikulturalisme dapat menjadi common platform dalam mendesain pendidikan khususnya dalam praktik pembelajaran yang berbasis Bhinneka Tinggal Ika. ${ }^{13}$

Jika dianalisis sebenarnya ada perbedaan mendasar antara pendidikan berbasis multikultural dengan pendidikan berbasis Bhinneka Tunggal Ika. Dalam pendidikan berbasis multikultural, menganjurkan kepada peserta didik untuk saling menghargai asal usul dan perbedaan masing-masing dalam kehidupan nyata di masyarakat. Pendidikan multikultural yang dipraktikkan di Amerika Serikat atau Australia (sekarang) tergolong sebagai critical multiculturalism, sementara pendidikan yang berbasis Bhinneka Tunggal Ika dikategorikan sebagai soft multiculturalism. ${ }^{14}$

Ciri dari critical multiculturalism saling menghadapkan antar perbedaan pendapat dan pandangan atau ketidakpahaman antara kelompok etnis, budaya, agama, dan perbedaan lain, sehingga akan terjadi perbenturan di antara mereka. Tujuannya agar mereka saling buka kartu dan secara terang-terangan menjelaskan dan menguraikan perbedaan pandangan. Dengan cara ini maka di antara mereka akan terbuka ruang agar orang atau kelompok dapat berdialog dengan sungguh-sungguh dari tingkat anak-anak sampai orang dewasa. Dengan cara ini, secara berangsur-angsur mereka saling memahami dan menghargai pendapat orang lain. Salah satu hal yang diharapkan adalah akan munculnya suasana keterbukaan dan keinsafan diri sendiri atas perbedaan etnik, budaya, agama atas dasar pengalaman dan keyakinan sendiri. ${ }^{15}$

\footnotetext{
13 Azyumardi Azra, Pendidikan Multikultural; Membangun Kembali Indonesia Bhineka Tunggal Ika, dalam Tsaqofah, Vol. I, No. 2, tahun 2003, hal. 19.
} 
Sementara itu pendidikan yang berbasis Bhinneka Tunggal Ika, tergolong sebagai pendidikan soft multiculturalism. Dalam pelaksanaannya pendidikan jenis ini digambarkan dengan suasana harmonis antar kelompok etnis, budaya, maupun agama. Dalam kenyataanya mereka itu tidak pernah ada ruang untuk saling berdialog secara serius dan terbuka tentang perbedaan masing-masing. Bentuk pendidikan yang sering dilakukan adalah dalam bentuk festival kesenian Nusantara, lagulagu daerah, pakaian adat, seperti yang sering dipertontonkan di Taman Mini Indonesia Indah (TMII), media TVRI dan acara perayaan hari besar nasional di sekolah maupun instansi lainnya. Kadang-kadang dilakukan pula dalam pembelajaran di kelas, dengan cara guru mengenalkan perbedaan adat-istiadat di Indonesia. Pendidikan multikultural seperti ini tidak efektif untuk membentuk sikap dan pemahaman yang kritis, karena hanya bersifat seremonial belaka. Soft multiculralism hanya dapat membuka mata kita tentang banyaknya variasi, jumlah, dan banyaknya pilihan adat istiadat, agama, budaya, etnis dan lain-lain. Akan tetapi sangat sulit untuk dapat meningkatkan kesadaran atas kepentingan nilai-nilai dan kepercayaan dalam kehidupan serta harga diri suatu komunitas. ${ }^{16}$ Untuk dapat mencapai tujuan yang ideal, maka pendidikan multikultural harus dilaksanakan secara lebih kritis.

Harus diakui bahwa permasalahan multikulturalisme masih merupakan ancaman bagi Indonesia. Sebagai bukti dalam sepuluh tahun terakhir ini masih saja terjadi peristiwa tragis yang melanda sejumlah daerah, yang disebabkan oleh perbedaan agama, budaya, suku atau etnis. Jadi adanya keberagaman di negeri ini masih berpotensi sebagai pemicu konflik dalam bentuk kekerasan, penyerangan, pengrusakan, pembakaran, penganiayaan, penangkapan, dan intimidasi. Permasalahan multukulturalisme yang tercermin dalam berbagai peristiwa sebenarnya merupakan produk sosial yang disebut habitus. Sering diartikan habitus sebagai suatu tindakan pengkondisian yang dikaitkan dengan keberadaan suatu kelas sosial, yaitu kelas dominan pemegang kekuasaan. Pengkondisian dapat dilakukan melalui media massa dan

\footnotetext{
16 Ibid, h. 20-21.
}

pendidikan, karena kedua elemen itu dipandang sebagai sarana yang sangat efektif untuk menyebar luaskan wacana. ${ }^{17}$

Berdasarkan pada kenyataan seperti itu maka perlu segera dicari jalan keluar agar multikultural tidak lagi menjadi masalah yang membahayakan bagi kehidupan dan keutuhan bangsa. Diperlukan upaya pengkondisian melalui bidang pendidikan ke arah yang positif. Perlu segera diwacanakan, dirancang dan dilakukan kebijakan tentang pendidikan yang berbasis multikulturalisme format baru yang bersifat lebih kritis (critical multiculturalism).

\section{Format Baru Pendidikan Berbasis Multikultural}

Dewasa ini disinyalir tengah terjadi disintegrasi bangsa yang ditengarai masih sering munculnya perilaku anarkhis di berbagai daerah. Diduga kuat salah satu penyebab dari masalah yang memprihatinkan itu adalah karena sebagian mayarakat tidak lagi memahami sejarah bangsanya yang ditandai oleh semangat pluralisme yang tercermin dalam semboyan Bhinneka Tunggal Ika. Sebagai warga masyarakat yang merasa ikut bertanggungjawab terhadap kelangsungan hidup bangsa dan negara, sudah sepantasnya kita berbuat sesuatu untuk mempersiapkan masa depan yang lebih baik. Harapan ini kiranya dapat dicapai apabila masyarakat terutama generasi mudanya sebagai calon pemimpin masa depan memiliki kualitas integritas yang memadai. Untuk urusan masa depan mereka memang harus mampu memegang peran yang sangat sentral.

Hal ini tercermin dalam pepatah lama, bahwa generasi muda adalah bunga dan harapan bangsa. Pepatah ini memiliki makna, bahwa generasi muda sepenuhnya bertanggungjawab terhadap kelangsungan hidup bangsa dan negaranya. Agar dapat memenuhi harapan itu maka sedini mungkin mereka perlu mempersiapkan diri, sehingga pada saatnya nanti siap tampil sebagai pemimpin yang tangguh, baik secara fisik, intelektual, maupun moral. Sebagai bekal yang mutlak diperlukan adalah iman dan taqwa, ilmu pengetahuan dan teknologi yang diperoleh melalui proses pendidikan secara sungguh-sungguh. Sebagai

\footnotetext{
17 Hilda Kurniawan, Media Pendidikan Dan Multikulturalisme: http://
} komjakarta.org/media-pendidikan-dan-multukulturanisme.htm\#more, 2010, h. 1. 
bunga dan harapan bangsa generasi muda dituntut pula untuk mempraktikkan budi pekerti yang luhur sesuai dengan nilai-nilai budaya dan moral bangsa.

Dengan budi pekerti yang luhur semacam itu para pemuda nantinya akan dapat menampilkan diri sebagai pemimpin yang berkualitas tinggi. Kesiapan mental dan ketinggian moral itu pada gilirannya merupakan prasyarat bagi terwujudnya kepemimpinan dan pemerintahan yang bersih dan berwibawa. Untuk menunjang cita-cita yang mulia itu, salah satu syaratnya diperlukan pemahaman nilai yang terkandung dalam sejarah bangsanya. Dengan pemahaman nilai semacam itu berarti upaya pembinaan dan pembangunan kharakter bangsa (nation building) dapat berproses dengan baik. Melalui pelaksanaan pendidikan yang berbasis multikultural secara terintegrasi dapat diharapkan akan tertanam semangat rela berkorban dan semangat persatuan, yang semuanya mengacu kepada upaya menjaga dan memelihara keutuhan bangsa serta negara ini.

Pengalaman sejarah perlu disadari, bahwa untuk mewujudkan keutuhan bangsa harus dapat menjaga perpaduan tiga unsur, yaitu: 1) Kemauan untuk bersatu "la desir d'etre esemble" (Ernest Renan). 2) Merasa senasib dan sepenanggungan "eine aus Schiksals-gemeinschaft erwachsent charakter-gemeinschaft' (Otto Bouwer), 3) Persatuan antara orang dan tempat sesuai dengan kenyataan Nusantara (Bung Karno). Dalam kenyataannya keterikatan masyarakat Indonesia yang terdiri dari berbagai budaya dan etnis sering mengalami masa-masa surut sulit, karena dihadapkan pada keanekaragaman.

Masa-masa sulit itu ternyata dapat diatasi, jika diingatkan kembali dengan semboyan dan pandangan hidup Bhinneka Tunggal Ika, yang berarti keanekaragaman kelompok. Dalam hal ini, maka semboyan Bhinneka Tunggal Ika diyakini sebagai sumber kekuatan. Dua hal itu selalu tampak sebagai kontradiksi. Namun keutuhan bangsa menuntut persyaratan dua hal itu merupakan perpaduan yang baku. Hal ini mengingat nasionalisme tetap dapat dipertahankan, jika benar-benar disadari kondisi yang dituntutnya. Pertama, setiap kelompok etnis secara mandiri mengolah keunggulankeunggulan budayanya yang khas anggotanya (diversity). Kedua, keunggulan yang khas itu harus mendapat peluang yang sama (equality). Ketiga, tersedianya bidang-bidang persoalan, di mana keunggulan yang beraneka ragam itu bekerja sama menghasilkan kekuatan yang jauh lebih besar dari sekedar jumlahnya. ${ }^{18}$

Suatu bangsa yang dibangun berdasarkan pada keanekaragaman seperti Indonesia, jika mampu mewujudkan tiga kondisi itu akan tetap tampil sebagai kesatuan, kendati terdiri dari aneka ragam kelompok etnis dan budaya (status diversitatis). Itulah status Bhinneka Tunggal Ika. Jika sampai terjadi pengutamaan satu kelompok, maka kemampuan yang beragam (diversity) akan berubah menjadi perbedaan martabat (bierarchi). Bersamaan dengan itu, peluang yang sama (equality) berubah menjadi perlakuan pilih kasih (discriminatory). Dengan demikian koordinasi kemampuan (synergy) sirna oleh pertarungan kemampuan (contradictory). Perubahanperubahan semacam itu akan membawa negara nasional yang berdasar pada keberagaman ke jurang permusuhan antarkelompok etnis (status bostilis) atau saling menghancurkan (status belli). Setelah itu negara bangsa akan hancur dan sebagai gantinya kemungkinan yang akan muncul adalah negara wangsa atau dinasti. ${ }^{19}$

Untuk menghindari dampak negatif dari perkembangan kondisi masyarakat Indonesia dewasa ini, maka perlu dirancang, dikembangkan dan dipraktikkan model pendidikan yang berbasis pada multikultur yang tepat untuk menjawab tantangan. Seperti kita ketahui, bahwa pendidikan adalah merupakan usaha yang secara sengaja dan terencana untuk mewujudkan suasana belajar agar peserta didik dapat secara aktif mengembangkan potensi dirinya. Dengan cara itu peserta didik memiliki kekuatan spiritual keagamaan, pengendalian diri, kepribadian, kecerdasan, ahlak mulia, serta keterampilan yang diperlukan untuk dirinya, masyarakat, bangsa dan negara. Sementara itu, pendidikan berbasis multikultural diartikan sebagai proses pengembangan sikap dan tingkah laku seseorang atau kelompok orang sebagai usaha mendewasakan manusia melalui proses pembelajaran, pelatihan, perbuatan, dan melaui cara-cara mendidik serta menghargai pluralitas

\footnotetext{
18 Op.Cit., h. 7.

19 Ibid, h. 8.
} 
dan heterogenitas secara humanistik. ${ }^{20}$

Pendidikan yang berbasis multikultur harus dapat memberi pemahaman tentang keberadaan masyarakat plural yang membutuhkan ikatanikatan keadaban, yang berupa pergaulan antar budaya yang diikat oleh suatu peradaban. Tentu saja ikatan tersebut dibangun oleh nilainilai universal kemanusiaan, yang ditransfer kepada masyarakat agar menemukan tujuan kepemilikan dan kelanggengan. Kepemilikan nilai-nilai universal itu dapat melembaga dalam masyarakat untuk mewujudkan budaya luhur, sehingga akan tercipta masyarakat yang aman, tertib, berwibawa, dan bermartabat. Untuk dapat memahami pendidikan multikultural, perlu dipahami karakteristik budaya dan wilayah budaya. Pemahaman terhadap karakteristik budaya antara lain meliputi budaya sebagai suatu hal yang general sekaligus sebagai suatu yang spesifik. Di samping itu budaya juga merupakan sesuatu yang dapat dipelajari, sebagai suatu simbol, sebagai milik bersama, sebagai atribut individu, budaya juga sebagai suatu model, dan budaya sebagai suatu yang bersifat adaptif. ${ }^{21}$ Mengenai wilayah budaya dapat diartikan sebagai :

1. Subkultural, merupakan suatu perbedaan karakteristik budaya dalam suatu kelompok masyarakat.

2. Kultur nasional, yang berbentuk aneka ragam pengalaman, sifat dan nilai-nilai yang digunakan oleh warga negara yang berada dalam suatu negara.

3. Kultur internasional, terbentuk dari tradisi kultural yang meluas melampau batas-batas wilayah nasional sebuah negara melalui proses penyebaran (diffusion), yaitu proses penggambungan antar dua kultur atau lebih melalui beberapa cara, seperti migrasi, perkawinan, media massa, atau bahkan film. ${ }^{22}$

Dalam era global dewasa ini pendidikan yang berbasis multikultural menjadi pilihan yang sangat penting. Hal ini mengingat pendidikan berfungsi untuk memanusiakan manusia,

20 I Made Suparsa, peranan Multikultur Dalam Pendidikan Nasional; http://suparsa.blogspot.com/2010/01/peranan-multicultur-dalam pendidikan. html, 2010, h. 1.

21 Ibid, h. 1

22 Ibid, h. 2. sehingga perlu ditempuh langkah tertentu untuk mempertahankan visi dan misi pendidikan multikultural di Indonesia. Berkaitan dengan itu, maka langkah-langkah yang perlu ditempuh adalah sebagai berikut:

1. Meningkatkan efisiensi dan efektivitas manajemen pendidikan.

2. Menciptakan kelembagaan agar daerah mempunyai peranan keterlibatan yang besar dalam penyelenggaraan pendidikan.

3. Mendorong peran serta masyarakat termasuklembagasosial kemasyarakatan dan dunia usaha sebagai mitra dari pihak pemerintah dalam pembangunan dan penyelenggaraan pendidikan.

4. Menyediakan fasilitas yang memadai agar peserta didik dapat tumbuh dan berkembang secara sehat, dinamis, kreatif, dan produktif.

5. Menciptakan sistem pendidikan yang proatif dan fleksibel.

6. Menciptakan suasana proses pembelajaran yang mampu membangkitkan dan menumbuhkembangkan kreativitas, membangun inovasi, serta minat dan semangat belajar.

7. Menanamkan kecintaan terhadap ilmu pengetahuan, teknologi dan seni sejak pendidikan usia dini.

8. enumbuhkembangkan daya juang, profesionalisme dan wawasan keunggulan.

9. Menumbuhkembangkan sikap hidup hemat, cermat, teliti, tekun dan disiplin.

10. Menumbuhkembangkan moral dan budi pekerti yang luhur sebagai perwujudan dari keimanan dan ketakwaan tarhadap Tuhan. ${ }^{23}$

Untuk memahami lebih jauh tentang pendidikan berbasis multikultural, perlu pula dikemukakan di sini tentang ideologi yang menjadi landasan pendidikan. Ideologi pendidikan merupakan nilai-nilai landasan ideal yang harus diimplementasikan dalam seluruh aktivitas pendidikan. Salah satu ideologi pendidikan multikultural adalah ideologi sirkularism. Ideologi sirkularisme merupakan 
ideologi pendidikan yang memberikan perhatian terhadap hubungan yang setara antara manusia dengan alam, manusia dengan manusia, manusia dengan Tuhan, dan antara manusia dengan dirinya sendiri. Ideologi ini menghendaki perlakuan segala sesuatu yang tepat pada hakhak yang melekat pada obyeknya. Dengan demikian, pendidikan berbasis multikultural terdapat beberapa pemahaman. Menurut Suparsa diperlukan tiga pemahaman yaitu: ${ }^{24}$

1. Pendidikan multikultural memandang dan meyakini pentingnya positioning, yaitu menempatkan sesuatu pada tempatnya, sesuai dengan nilai keadilan dan keseimbangan.

2. Pemetaan dalam pendidikan multikultural sebagi suatu keniscayaan, untuk mencapai hasil sesuai dengan yang dikonsepkan. Pemetaan berujung pada keragaman, heterogenitas, pluralitas, dan deversitas sebagai suatu keharusan dalam pendidikan multikultural.

3. Pendidikan multikultural adalah pendidikan untuk membentuk jati diri seseorang, yang berupaya menyeragamkan seluruh aspek kemanusiaannya. Ciri khas pendidikan multikultural selalu menghadapi keragaman pluralistik, heterogenitas, etnik, agama, budaya, dan suku sehingga dapat mengangkat potensi seseorang dengan jati dirinya masingmasing.

Untuk dapat meningkatkan kualitas proses pembelajaran dalam pendidikan yang berbasis multikultural memerlukan guru dengan karaktaristik tertentu. Menurut Aldridge dalam Rosyada, karakteristik guru yang diperlukan adalah sebagai berikut:

1. Guru harus mampu menciptakan situasi kelas yang tenang, bersih, tidak stress, dan sangat mendukung untuk pelaksanaan pembelajaran.

2. Guru harus menyediakan peluang bagi para siswa untuk mengakses seluruh bahan dan sumber informasi untuk belajar.

3. Guru perlu menggunakan model cooperative learning melalui diskusi dalam kelompok-kelompok kecil, debat, atau rool playing.

4. Guru harus mampu menghubungkan informasi baru pada sesuatu yang sudah diketahui oleh siswa, sehingga mudah untuk mereka pahami.

5. Guru harus mampu mendorong siswa untuk mengerjakan tugas-tugas, dengan melakukan kajian dan penelusuran pada hal-hal baru dan mendalam.

6. Guru harus memiliki catatancatatan kemajuan dari semua proses pembelajaran siswa, tugas-tugas individual, sehingga dapat melakukan evaluasi dalam bentuk portofolio. ${ }^{25}$

Kemudian mengenai Standar Kompetensi (Kompetensi Inti) pendidikan berbasis multikultural adalah: "Menjadi warga negara yang mampu hidup berdampingan bersama warga negara lainnya tanpa membedakan agama, ras, bahasa dan budaya dengan menghormati hak-hak mereka, memberi peluang kepada semua kelompok untuk mengembangkan budayanya serta mampu mengembangkan kerja sama untuk mengembangkan bangsa menjadi bangsa besar yang dihormati dan disegani di dunia internasional". ${ }^{26}$

Dari Standar Kompetensi (Kompetensi Inti) tersebut dapat pula dirinci Kompetensi Dasarnya, sebagai berikut:

1. Menjadi warga negara yang menerima dan menghargai perbedaan etnik, agama, bahasa dan budaya dalam struktur masyarakat.

2. Menjadi warga negara yang dapat melakukan kerja sama multietnik, multi kultur, dan multi religi dalam konteks pengembangan ekonomi dan kekuatan bangsa.

3. Menjadi warga negara yang mampu menghormati hak-hak individu warga negara tanpa membedakan latar belakang etnik, agama, bahasa dan budaya dalam semua sektor sosial, pendidikan, ekonomi, pilitik dan lainnya, bahkan untuk memelihara bahasa dan mengembangkan budaya 
mereka.

4. Menjadi warga negara yang memberi peluang pada semua warga negara untuk dapat diwakili gagasan dan aspirasinya dalam lembaga-lembaga pemerintahan, baik eksekutif maupun legislatif.

5. Menjadi warga negara yang mampu mengembangkan sikap adil dan mengembangkan rasa keadilan terhadap semua warga negara tanpa membedakan latar belakang etnik, agama, bahasa dan budaya mereka.

Dari lima Kompetensi Dasar tersebut tampak tidak ada pertentangan dengan norma hukum maupun etika dalam ajaran Agama Islam ataupun pemikiran keagamaan yang dikemukakan oleh para pemuka agama lainnya. Bahkan kini sudah teradopsi sebagai nilai-nilai bangsa yang harus menjadi dasar pertimbangan dalam mengembangkan perilaku atau kebijakan dalam kehidupan sosial. ${ }^{27}$

Namun demikian pendidikan berbasis multikultur sebagai salah satu upaya menjembantani kesenjangan antara keanekaragaman budaya dan etnik di Indonesia yang semakin diperparah dengan perkembangan budaya global, tentu masih memiliki kelemahankelamahan. Hal ini disebabkan proses sintesa dalam pembentukan budaya nasional masih berlangsung dan baru berada pada tahap transisi. Sementara itu masyarakat Indonesia dihadapkan pada tantangan baru yang lebih kompleks dan dengan skala yang lebih besar, yaitu ekspansi budaya global yang ditandai dengan segala kecanggihan sistem liberal, ekonomi, teknologi, dengan jaringan komunikasi modern yang mendukungnya. ${ }^{28}$ Dengan demikian, terjadilah suatu interaksi kebudayaan yang sangat pesat dan menyeluruh, yang mampu mengguncang simpul-simpul serat budaya etnis di tingkat lokal maupun nasional yang sedang dalam proses metamorfose pembentukan identitas baru. Sifatsifat agresif budaya global ini sering dirasakan sebagai imperialisme baru yang tidak jarang pula ditafsirkan sebagai suatu ancaman yang tak terhindarkan. Anggapan yang negatif terhadap

\footnotetext{
$27 \quad$ Ibid, h. 6.

28 Kenichi Ohmae, The End of The Nation State: The Rise of Regional Economies, New York: The Free Press Paperbacks, 1995, h. 3.
}

budaya global mengakibatkan munculnya reaksi primordial dan emosional dengan cara mengisolasi diri maupun perlawanan agresif lainnya.

Menurut I Made Suparsa, ${ }^{29}$ permasalahan pendidikan berbasis multikultur dalam masyarakat berkaitan dengan proses, fungsi, dan hasil pendidikan, antara lain:

1. Fungsi dan tujuan pendidikan multikulural dianggap kurang melekat pada pelaksana dan pelaksanaan.

2. Prinsip pendidikan multikultural kurang menjunjung tinggi demokrasi, keadilan, dan hak asasi manusia.

3. Evaluasi pendidikan multikultural dalam rangka pengendalian mutu secara nasional seringkali dibelokkan untuk kepentingan tertentu.

Oleh sebab itu untuk dapat mengantisipasi berbagai kelemahan yang ada, perlu dikembangkan model pendidikan multikultural yang sesuai, agar generasi muda mampu berkembang dan hidup harmonis di tengahtengah beragamnya budaya, baik budaya etnis maupun budaya global. Penyelenggaraan pendidikan yang berbasis pada multikultural didasari oleh kerangka tujuan pendidikan nasional,yang tercermindalam Undang-undangNo. 20 Tabun 2003 tentang Sistem Pendidikan Nasional. Undang-undang tersebut menyebutkan, bahwa "Pendidikan diselengarakan secara demokratis dan berkeadilan serta tidak diskriminatif dengan menjunjung tinggi hak azasi manusia, nilai keagamaan, nilai kultural, dan kemajemukan bangsa". Dengan mengurangi beberapa kelemahan yang ada, diharapkan pelaksanaan pendidikan yang berbasis multikultur, mampu mengembangkan karakter peserta didik sesuai dengan tujuan pedidikan yang ingin dicapai.

\section{Kesimpulan}

Ditinjau dari segi sosial budaya dalam era global seperti sekarang ini, Indonesia masih dihadapkan pada dua tantangan besar, yaitu tantangan yang berupa proses integrasi keberagaman budaya, agama, dan etnis dan yang kedua adalah tantangan dari masuknya arus budaya global yang bersifat ekspansif. Kedua tantangan tersebut perlu mendapat perhatian 
serius, agar Indonesia dapat mempertahankan eksistensinya sebagi negara bangsa. Hal ini merupakan tugas penting bidang pendidikan yang harus tampil sebagai ujung tombak penentu masa depan bangsa.

Melalui pendidikan dengan berbasis multikultur, dunia pendidikan dituntut untuk menghasilkan sumber daya manusia yang demokratis, memahami dan menghargai perbedaan dan keanekaragaman budaya dan etnis yang ada dalam masyarakat, serta mampu mengikuti kemajuan ilmu dan teknologi. Hal ini sesuai denga jiwa UU RIN No. 20 tahun 2003 tentang Sistem Pendidikan Nasional, yang menyatakan, bahwa pendidikan merupakan upaya untuk mewujudkan tujuan pembangunan nasional dalam rangka mengembangkan kemampuan dan membentuk watak serta peradaban bangsa yang bermartabat.

Untuk dapat mencapai tujuan yang ditetapkan, maka perlu segara dirancang dan ditetapkan kebijakan pendidikan yang sesuai dengan tantangan yang tengah dihadapi, baik tantangan dari dalam maupun dari luar. Di samping itu individu-individu yang ada dalam organisasi pendidikan harus memiliki kemampuan yang memadai untuk mengemban tugas nasional. Guru sebagai bagian dari organisasi sekolah memiliki kewajiban untuk melaksanakan serangkaian tugas sesuai dengan fungsi yang harus dijalankannya. Sebagai seorang manajer pembelajaran guru berkewajiban memberi pelayanan kepada siswanya terutama dalam kegiatan pembelajaran di kelas sesuai dengan kebijakan pendidikan nasional. Guru harus menguasai materi pelajaran, strategi dan model pembelajaran, serta kemampuan pembimbingan kepada siswa untuk mencapai prestasi yang tinggi, mengembangkan kemampuan dan membentuk watak serta peradaban bangsa yang bermartabat.

\section{Daftar Pustaka}

Azra, Azyumardi, "Pendidikan Multikultural; Membangun Kembali Indonesia Bhineka Tunggal Ika", dalam Tsaqafah, Vol. I, No. 2, tahun 2003.

Depdiknas, Undang-Undang R I Nomor 20 Tentang Sistem Pendidikan Nasional, Bandung, Citra Umbara, 2003.

Depdiknas, Stan Pembangunan Pendidikan Nasional, Jakarta, Depdiknas, 2008.

Parakitri, Negara Bangsa atau Negara Wangsa, Salatiga. Seminar tentang Nasionalisme, 1993.

Kartodirdjo, S., Fungsi Sejarah Dalam Pembangunan Bangsa: Kesadaran Sejarah, Identitas, dan Kepribadian Nasional, Semarang, Seminar Sejarah Nasioanal V, 1991.

Kayam, U., Transformasi Budaya Kita, Jakarta, Sinar Harapan, 1981.

Kurniawan, Hilda, Media Pendidikan Dan Multikulturalisme: http://komjakarta. org / media-pendidikan-danmultukulturanisme.htm\#more, 2010.

Natsir, M., MencariCorakPerdamaian Dengan Sistem Multikultur, http://ace-informasibudaya. blogspot.com/2010/01/perdamaiansistem-kultur.html, 2010.

Ohmae, Kenichi, The End of The Nation State: The Rise of Regional Economies, New York: The Free Press Paperbacks, 1995.

Rosyada, Dede, Pendidikan Multikultural Melalui Pendidikan Agama Sebuab Gagasan Konsepsional: http://www.google.co.id/ search?hl=id\&client $=$ firefox - a\&rls $=$ org. mozilla:en-US:official\&q=MULTI+KUL TUR\&start $=30 \& \mathrm{sa}=\mathrm{N}, 2010$.

Soedjatmoko, Keprihatinan Tentang Masa Depan, Yogyakarta,Tiara Wacana, 1999. 
Suparsa, I Made, peranan Multikultur Dalam Pendidikan Nasional; http://suparsa. blogspot.com/2010/01/perananmulticultur-dalam pendidikan.html, 2010.

Sowell, Thomas, Mosaik Amerika: Sejarah Etnis Sebuah Bangsa, Jakarta, Pustaka Sinar Harapan, 1989.

Supriadi, D, Reformasi Pendidikan Dalam Konteks
Otonomi Daerah, Yogyakarta, Adicita, 2000.

Undang-Undang Dasar 1945 Dan Amandemennya, 2008, Jakarta, Media Centre.

Watson, Bill, Multiculturalism: Its Strenth and Weaknesses, dalam JPIPS, No.23, Tahun XIII, Desember 2004. 